\title{
Significance of low body weight in ovulatory dysfunction after stopping oral contraceptives
}

\author{
K W HANCOCK, J S SCOTT, N M PANIGRAHI, S R STITCH
}

British Medical fournal, 1976, 2, 399-401

\section{Summary}

In a group of patients who developed ovulatory dysfunction on stopping oral contraception the mean body weight of those with previously regular cycles was significantly lower than that of women who had had ovulatory dysfunction before oral contraception and also that of a control group. Women of low body weight may be at particular risk of developing post-pill amenorrhoea even when there is no history pointing to ovulatory dysfunction. This should be considered when selecting a form of contraception in such women.

\section{Introduction}

In 1966 Shearman $^{1}$ drew attention to the occurrence of persistent amenorrhoea in women who had discontinued oral contraception. Subsequently several reports have described the condition, which has come to be termed "post-pill amenorrhoea." ${ }^{-6}$ Considerably fewer than $1^{\circ}{ }_{0}$ of oral contraceptive users develop post-pill amenorrhoea. ${ }^{+i} 8$ The patients affected, however, are often young and have elected to defer pregnancy only to find that when they want to conceive ovulation fails. Efforts have therefore been made to identify women at particular risk. All published series have contained a significant proportion of patients who suffered from menstrual and presumed ovulatory dysfunction before taking oral contraceptives, ${ }^{2-6}$ and the presence of such dysfunction has therefore been emphasised as a possible contraindication to oral contraception. ${ }^{5}$ Nevertheless, many patients developing amenorrhoea have had an impeccably regular cycle before taking the pill, and dysfunction in this group is particularly disturbing. We reviewed those patients with previously regular cycles who were referred to the university unit at the Hospital for Women at Leeds. We wanted to ascertain whether this group showed any particular features before taking oral contraceptives that might serve to identify the likelihood of complications after stopping contraception.

\section{Patients and methods}

In the seven years 1968-74 64 patients presented with ovulatory dysfunction after they had stopped oral contraception. The yearly incidence of such cases is shown in table I. Forty-nine of the women had been amenorrhoeic for at least 12 months and 15 were menstruating fewer than five times a year (oligomenorrhoea). Thirty-four patients had suffered from some form of menstrual dysfunction before starting oral contraception, but 30 had had reasonably regular cycles of between 28 and 42 days. The menstrual pattern before and after oral contraception is shown in table II.

Department of Obstetrics and Gynaecology, University of Leeds $\mathrm{K}$ W HANCOCK, MB, MRCOG, senior lecturer J S SCOTT, MD, FRCOG, professor

N M PANIGRAHI, MB, MS, Smith and Nephew foundation fellow (present address: Department of Obstetrics and Gynaecology, SCB Medical College, Cuttack, India)

Division of Steroid Endocrinology, Department of Chemical Pathology, University of Leeds, Leeds LS2 9NG

S R STITCH, PHD, FRIC, professor
TABLE I-Number of patients referred each year with post-pill ovulatory dysfunction 1968-74

\begin{tabular}{c|c|c|c|c|c|c|c}
\hline Year: & 1968 & 69 & 70 & 71 & 72 & 73 & 74 \\
No of cases & 5 & 10 & 7 & 18 & 14 & 7 & 3 \\
\hline
\end{tabular}

TABLE II-Menstrual pattern before and menstrual disorder after oral contraception

\begin{tabular}{l|c|c|c}
\hline \multicolumn{1}{c|}{$\begin{array}{c}\text { Cycle before } \\
\text { pill }\end{array}$} & $\begin{array}{c}\text { No of } \\
\text { women }\end{array}$ & $\begin{array}{c}\text { Menstrual disturbance on } \\
\text { stopping pill }\end{array}$ \\
\hline $\begin{array}{l}\text { Amenorrhoea } \\
\begin{array}{l}\text { Oligomenorrhoea } \\
\text { Regular cycle }\end{array}\end{array}$ & 10 & $\begin{array}{c}\text { Oligomenorrhoea } \\
\text { Amenorrhoea }\end{array}$ & 10 \\
\hline
\end{tabular}

Patients were weighed at their first visit and asked if any significant weight change had occurred since they started oral contraception. The height of some of the women was measured. When the patient's height was available her "ideal" weight, corresponding to the population mean norm ${ }^{9}$ for her height, sex, and age at the time of presentation, was determined. Each patient underwent $x$-ray examination of the pituitary fossa and a metyrapone test. Endogenous ovarian activity was assessed by urinary oestrone assays, microscopy of cervical mucus smears and culdoscopic visulisation of the ovaries with dye testing for tubal patency. When pregnancy was desired the male partner was investigated and a post-coital test performed.

When indicated the appropriate form of ovulation induction treatment was started.

\section{Results}

There was no radiological evidence of a pituitary lesion in any patient, and no abnormality of pituitary-adrenal function was shown by the metyrapone test. The appearance of the ovaries is shown in table III.

Body weights-The mean weights of patients with previously regular cycles and those with pre-existing ovulatory dysfunction are shown in table IV, where they are compared with the mean body weight of a control group of 100 women with regular cycles who were starting oral contraception. The mean body weight of the group with previously regular cycles was significantly lower than that of patients with

TABLE III-Appearance of ovaries in post-pill ovulatory dysfunction

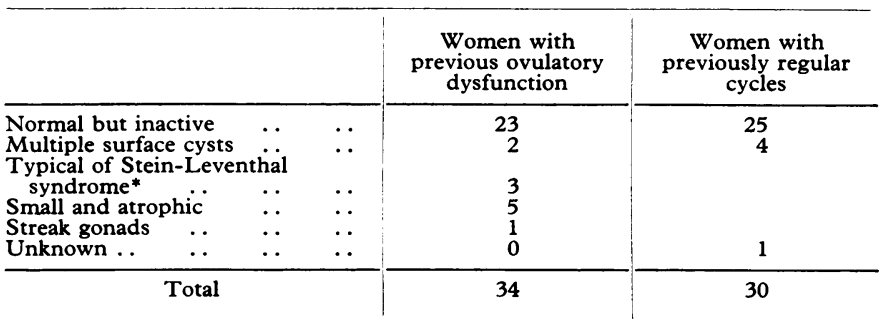

*Large, smooth-surfaced ovaries typical of the subcapsular polycystic state found in the Stein-Leventhal syndrome.

TABLE IV-Mean body weight in patients with post-pill ovulatory dysfunction

\begin{tabular}{l|c|c|c}
\hline & $\begin{array}{c}\text { Women with } \\
\text { previously regular } \\
\text { cycles }\end{array}$ & $\begin{array}{c}\text { Women with } \\
\text { previous ovulatory } \\
\text { dysfunction }\end{array}$ & Controls \\
\hline $\begin{array}{l}\text { No of women } \\
\text { Mean }( \pm \mathrm{SD}) \text { weight }(\mathrm{kg})\end{array}$ & $50 \cdot 45 \pm 8.9$ & $56.5 \pm 9 \cdot 41$ & $57.3 \pm 7.6$ \\
\hline
\end{tabular}




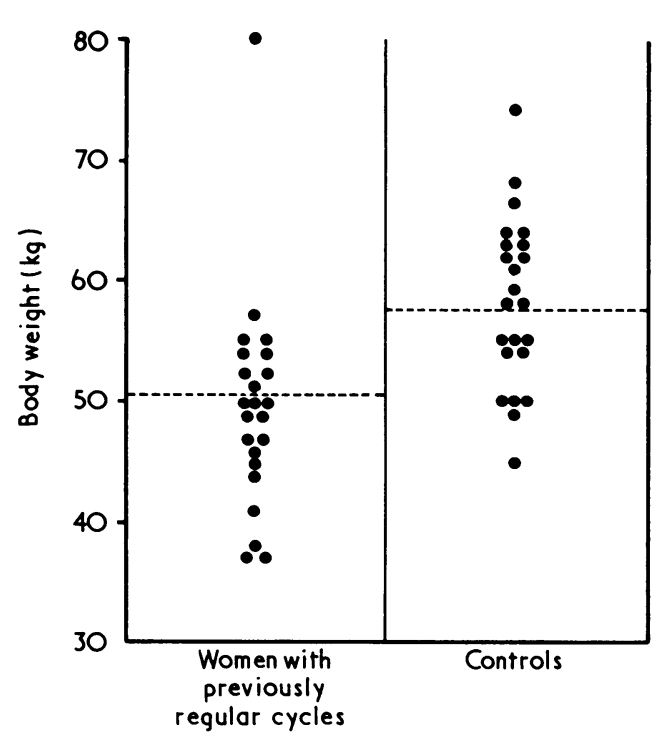

FIG 1-Body weights of 23 patients with post-pill ovulatory dysfunction (and previously regular cycles) and controls matched for age and parity.

previous ovulatory dysfunction $(t=2.444 ; \mathrm{P}<0.01)$ and that of the control group $(t=4.095 ; \mathrm{P}<0.001)$. We matched for age and parity 23 patients who had previously had regular cycles with subjects from the control group (fig 1). The significant difference between the mean body weights of the two groups persisted $(t=3.36 ; \mathrm{P}<0.005)$. Only one patient reported any significant change in weight since starting oral contraception. She weighed $80 \mathrm{~kg}$ and had gained $22.5 \mathrm{~kg}$.

Actual body weight in relation to " $i d e a l$ " body weight-We obtained an ideal body weight for 22 of the patients with previously regular cycles. In fig 2 the actual body weight expressed as a percentage of the ideal weight is shown for these women. Only two women weighed more than their ideal, and in seven the actual body weight was less than $90 \%$ of the ideal weight.

Outcome-The outcome as regards ovulation and subsequent pregnancy in 25 of the patients with previously regular cycles is shown in table $\mathrm{V}$.

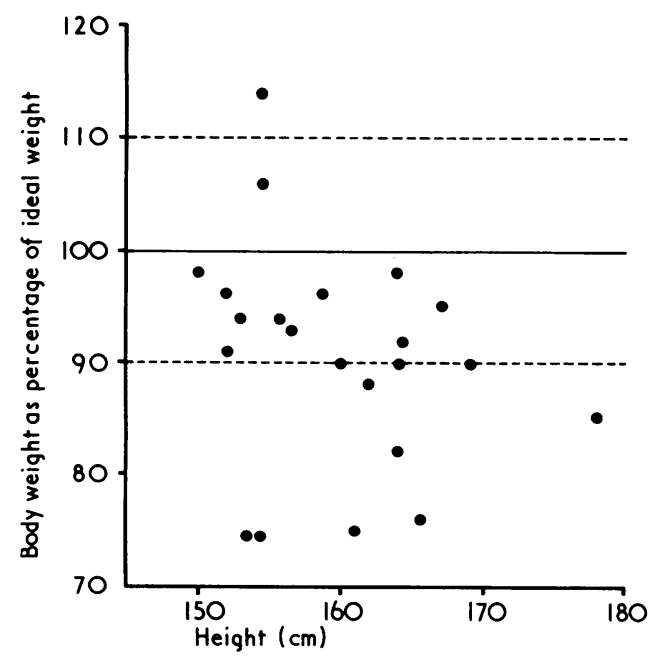

FIG 2-Body weights of 22 patients with post-pill ovulatory dysfunction (and previously regular cycles) expressed as a percentage of ideal weight.

TABLE $\mathrm{V}$-Outcome in post-pill amenorrhoea (in 25 women with previously regular cycles)

\begin{tabular}{|c|c|c|c|c|}
\hline & No treatment & Clomiphene & Gonadotrophins & Total \\
\hline $\begin{array}{l}\text { Ovulation } \\
\text { Pregnancy } \\
\text { Outcome } \\
\text { unknown }\end{array}$ & $\begin{array}{r}11 \\
3 \\
3\end{array}$ & $\begin{array}{l}3 \\
1\end{array}$ & $\begin{array}{l}8 \\
6\end{array}$ & $\begin{array}{r}22 \\
10 \\
3\end{array}$ \\
\hline
\end{tabular}

\section{Discussion}

Shearman and $S$ mith $^{10}$ have provided evidence for a causal rather than a coincidental relation between oral contraception and subsequent amenorrhoea, while Fries and Nillius ${ }^{11}{ }^{12}$ have suggested that psychogenic factors and weight reduction, particularly in association with dietary restriction, may be of aetiological importance. Our findings indicate that, in the absence of pre-existing ovulatory dysfunction, a low body weight, not necessarily associated with recent weight loss, is of major significance in the development of post-pill amenorrhoea. In the series of Fries and Nillius ${ }^{12}$ the body weights of $73.3 \%$ of their patients were more than $10 \%$ below the mean body weight for the female population in Sweden. This feature is not apparent in the case of other complications associated with oral contraception. The mean body weight of patients with complications other than amenorrhoea reported to the Committee on Safety of Medicines are shown in table VI, where they are compared with those of the groups in our study. The slightly higher mean weight of those with "other adverse effects" compared with that of our controls about to start on the pill possibly represents the weight gain experienced by some women on the pill.

TABLE VI-Mean body weights $( \pm S D)$ in patients with post-pill ovulatory dysfunction (and previously regular cycles) and patients with other adverse effects

\begin{tabular}{|c|c|c|}
\hline & $\begin{array}{c}\text { No of } \\
\text { subjects }\end{array}$ & $\begin{array}{c}\text { Body weight } \\
(\mathbf{k g})\end{array}$ \\
\hline 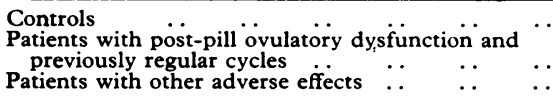 & $\begin{array}{r}100 \\
29 \\
319\end{array}$ & $\begin{aligned} 57 \cdot 3 & \pm 7 \cdot 6 \\
50 \cdot 45 & \pm 8 \cdot 9 \\
61 \cdot 3 & \pm 10 \cdot 3\end{aligned}$ \\
\hline
\end{tabular}

The most obvious explanation is that, perhaps on the basis of a dose:weight ratio, the standard oestrogen-progestogen preparation induces more profound suppression and consequently delays resumption of activity of the hypothalamic centres in patients of low body weight. Possible support for this view may be derived from the yearly incidence of patients referred with the condition (table I). After a steady rise to a peak in 1971 there has been a progressive fall in the number of cases each year. The statement of the Committee on Safety of Drugs ${ }^{13}$ in 1970 was followed by the general introduction of low-dose oestrogen formulations for contraception. Possibly the change in incidence may be partly attributable to the reduction in the oestrogen content of the preparations now used.

An alternative explanation for amenorrhoea may lie in the apparent influence of body weight on the function of the hypothalamic-pituitary-ovarian axis. There is some evidence for an association between the onset of the menarche and the attainment of a "critical" body weight ${ }^{14}$; in several samples the mean body weight was in the region of $47 \mathrm{~kg}{ }^{14}{ }^{15}$ In a study of the effect of luteinising hormone/follicle-stimulating hormonereleasing hormone (LH/FSH-RH) in patients with anorexia nervosa Palmer et al $^{16}$ observed an inverted response-that is, the FSH response was greater than that of $\mathrm{LH}$, a pattern that is characteristic of the prepubertal female. When the patient's body weight was restored to normal the response reverted to the normal adult pattern. When serial testing was carried out the conversion to the normal adult response occurred at a weight of about $45 \mathrm{~kg}$. Moreover, during the acute phase, patients suffering from anorexia nervosa may show secretion patterns of $\mathrm{LH}$ similar to those of a prepubertal girl. ${ }^{17}$ Successful weight gain and clinical remission is accompanied by recovery of a normal adult pattern.

The hypothalamus of the prepubertal girl is very sensitive to gonadal feedback suppression. Possibly in the adult of low body weight the hypothalamus is more susceptible to sustained suppression by exogenous steroids. 
In the absence of previous ovulatory dysfunction the prognosis in post-pill amenorrhoea is good, the ovaries remaining responsive to gonadotrophin stimulation, whether of endogenous or exogenous origin (table V). This is in keeping with the essentially normal appearance of the ovaries in this group (table III). Nevertheless, spontaneous resumption of ovulation may be delayed for many months, and when ovulation was induced in our patients gonadotrophin therapy with its attendant risks and costs often proved necessary (table V).

When considering methods of contraception in women who subsequently want to conceive, women of low body weight, who may be underweight or simply petite, should be included among those for whom an oestrogen-progestagen preparation is possibly contraindicated. It remains to be seen whether the introduction of the low-dose oestrogen preparations will reduce the incidence of what is now becoming the commonest recognised cause of secondary amenorrhoea.

We thank Dr W H Inman, principal medical officer, Committee on Safety of Medicines, for the data on body weights of patients reported to the Committee on Safety of Medicines, and Dr Michael Smith, chief medical officer, Family Planning Association, and the staff of the East Leeds Family Planning Clinic for access to similar data on women starting oral contraception.

\section{References}

1 Shearman, R P, Lancet, 1966, 2, 1110.

2 Halbert, D R, and Christian, D C, Obstetrics and Gynecology, 1969, 34, 161.

${ }^{3}$ Macleod, S C, et al, American fournal of Obstetrics and Gynecology, 1970, 106, 359.

4 Shearman, R P, Lancet, 1971, 2, 64.

5 Starup, J, Acta Obstetricia et Gynecologica Scandinavica, 1972, 51, 341.

6 Steele, S J, Mason, B, and Brett, A, British Medical fournal, 1973, 4, 343.

${ }^{7}$ Larsson-Cohn, U, Acta Obstetricia et Gynecologica Scandinavica, 1969, 48, 416.

8 Golditch, I M, Obstetrics and Gynecology, 1972, 39, 903.

${ }^{9}$ Kemsley, W F F, Annals of Eugenics, 1952, 16, 316.

10 Shearman, R P, and Smith, I D, Fournal of Obstetrics and Gynaecology of the British Commonwealth, 1972, 79, 654.

${ }^{11}$ Fries, H, and Nillius, S J, Acta Psychiatrica et Neurologica Scandinavica, 1973, 49, 653

12 Fries, H, and Nillius, S, Acta Psychiatrica et Neurologica, 1973, 49, 669.

${ }^{13}$ Committee on Safety of Drugs, British Medical fournal, 1970, 2, 231.

14 Frisch, R E, and Revelle, R, Science, 1970, 169, 397.

15 Johnston, F E, et al, American fournal of Diseases of Children, 1975, 129, 19.

16 Palmer, R L, et al, British Medical fournal, 1975, 1, 179.

17 Boyar, R M, et al, New England fournal of Medicine, 1974, 291, 861.

\section{Familial cancer on a Scottish island}

\section{R D HILL}

British Medical fournal, 1976, 2, 401-402

\section{Summary}

When the causes of death were determined in 18 relations of a child with Fanconi's anaemia 10 deaths were found to be due to carcinoma of various organs. Cases of osteogenic sarcoma, leukaemia, and Marfan's syndrome were also discovered among relatives. The family was from a remote community in the Hebrides and there was considerable intermarriage. Suggestive evidence of heterozygosity was found by chromosome analysis.

\section{Introduction}

Fanconi's anaemia was first described in 1927 in three brothers with pancytopenia and multiple congenital abnormalities. ${ }^{1}$ The condition is inherited as an autosomal recessive of low penetrance, and affected individuals have growth retardation; various congenital abnormalities, of which skeletal defects and faults in skin pigmentation are the most common; a progressive pancytopenia; and frequent chromosome breaks in fibroblast and lymphocyte cultures. It usually begins before the age of 10 and may terminate in acute myelogenous or monomyelocytic leukaemia.

Groups of patients with Fanconi's anaemia have been reported $^{2-5}$ in whom there appeared to be a definite increase in the incidence of leukaemia and other tumours, in both patients and their relatives (see table). The cell type in all reported cases has been acute myelogenous or monomyelocytic leukaemia. ${ }^{4}$ This is in striking contrast to the usual pattern of childhood leukaemia: in one series of 181 patients, ${ }^{6}$ for example, 168 had acute lymphoblastic leukaemia and only 13 acute myelogenous leukaemia.

There is only scant reference to a link with other types of neoplasm. Swift ${ }^{7}$ studied 474 relatives and found that 27 of the 102 deaths were due to neoplasms, as against an expected $17 \cdot 4 \pm 3 \cdot 8$ (SD) in an unselected population-a significant difference at the 0.05 level. There were also four neoplasms in relatives dying from other causes and eight in living relatives.

\section{Case report}

A 5-year-old girl from a Hebridean island (population 1350) was born on 5 May 1969 with bilateral dislocation of the hips and malformations of both thumbs. In January 1975 she was found to be very pale and listless, with haemoglobin $4 \mathrm{~g} / \mathrm{dl}$; white blood count $2.05 \times 10^{9} / 1\left(2050 / \mathrm{mm}^{3}\right)$, with polymorphs $0.44 \times 10^{9} / 1\left(440 / \mathrm{mm}^{3}\right)$; platelets $3 \times 10^{9} / 1\left(3000 / \mathrm{mm}^{3}\right)$; and reticulocytes $4 \%$. Fetal haemoglobin was grossly raised at $32 \%$. The peripheral film showed a normochromic, macrocytic anaemia with neutropenia and thrombocytopenia but no blast cells. Neutrophils in the buffy coat had partially defective granulations and a normoblast was present. The Ham test gave negative results.

Marrow smear showed patchy areas of cellular marrow intermingled with hypoplastic fatty areas. Megakaryocytes were reduced but myeloid and erythroid series were normally represented in the cellular areas. Red cell precursors, however, showed features of dyserythropoiesis-that is, multinuclearity, Howell-Jolly bodies, and late megaloblasts. Foamy reticulum cells were prominent, together with several tissue mast cells, characteristic of aplastic states. There was increased iron in the reticulum cells. There was no evidence of leukaemia.

These findings, coupled with the skeletal abnormalities, were thought to be typical of Fanconi's anaemia.

\section{Family studies}

The patient's parents were second cousins. Eighteen members of previous generations had died, $10(55 \%)$ from some form of neoplasm: 